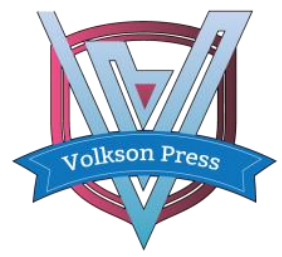

Economics, Finance and Statistics (EFS)

DOI : http://doi.org/10.26480/icefs.01.2018.24.28

\title{
ANALYSIS OF THE CREATIVE INDUSTRY VALUE OF URBAN LIGHTING FESTIVAL
}

\author{
Yue Wang, Jing Chen, Ran Xiao, Xiaoxiao Zeng \\ Huazhong University of Science and Technology Luoyu Road,Wuhan,China \\ *Corresponding Author's E-mail: 2593310901@qq.com
}

This is an open access article distributed under the Creative Commons Attribution License, which permits unrestricted use, distribution, and reproduction in any medium, provided the original work is properly cited.

\section{ARTICLE DETAILS}

\section{Article History:}

Received 12 March 2018

Accepted 12 April 2018

Available online 15 May 2018

\section{ABSTRACT}

In the era of the development of science and technology changes with each passing day, with the rapid development of lighting science and technology, people's growing material and psychological needs, to "culture" as the kernel, with "art" as the carrier of the creative industry arises at the historic moment. With the change of lighting technology, it has created more vitality space for urban life and extended the time of human communication activities. The lighting festival has gradually become a worldwide and phenomenal cultural activity which is popular with the public. In recent years, China's creative industry has been developing rapidly, and the urban lighting festival is a new field which is gradually recognized and valued by people, which provides new value for the creative industry.

\section{KEYWORDS}

Lighting festival, Creative industry, New media art design.

\section{INTRODUCTION}

Based on a study, the human life has become more and more inseparable from the light, the appearance of the light also allows the human activity time to extend, the activity space expands, the activity content is enriched [1]. In recent years, with the development of photoelectric technology and the extension of the connotation boundary of the creative industry, it has gradually developed into the urban lighting field, and the urban lighting has already jumped out of the original lighting function [2]. Under the packaging of art and design, the development of urban lighting festival has great impact on the urban creative industry [3].

\subsection{Creative Features of City Lighting Festival.}

\subsubsection{Spatial Adaptability.}

The original structure to the urban space as a basic element design, combined with the feature of urban space, to building, plaza, park, mountains, rivers and so on as the carrier, make full use of the important cities of artificial facilities, comprehensive design combined with the natural landscape, usually, epidermis of large buildings set for large projection screen, for building Mapping; The square is an independent display of the light design work; Artificial facilities and human-computer interaction can realize the communication between people and lights [4]. Based on the characteristics of urban spatial planning, the street node is used to set the unique rhythm of lights, and the spatial adaptability of urban lighting festival is demonstrated.

\subsubsection{Cultural Integration.}

The artistic design of the lighting is not only the dazzling technology accumulation, but also the exploration of art and the understanding of culture. The urban lighting festival, developed in the digital media leap, based on the story, ideas, values and other spiritual core embodiment [5]. On the basis of understanding the unique culture of the city, the design language of lighting art is endowed with a more contemporary artistic aesthetic feeling. Through the rendering of the urban lighting festival, the century-old town or the new city, under the light of the lighting, exhaled the unique urban cultural charm.

\subsubsection{Public Participation.}

Urban lighting festival often open multiple channels, inviting artists from all fields to participate, and stimulating local cultural revival and reproduction. The urban lighting festival provides more opportunities for young artists, and is a communication platform for education work in colleges and universities everywhere. In Guangzhou international lighting section, for example, each year attracting artists and art institutions from all over the world not only to participate in, also set a special area for "colleges and universities in Guangdong province lighting gallery", at that time, universities with its characteristics of teaching and education concept, education culture to form unique characteristics of the school, such as lighting art exhibits [6]. Such young art students show strong creativity and innovative spirit, and create more opportunities for the exploration of young talents. Public participation has broadened the reach of the audience and allowed such a culture to flourish in full name.

\subsection{Design of Urban Lighting Festival.}

\subsubsection{Building Projection.}

The lights of the traditional projection are done by white curtain, this not only has limited the size of the works and site requirements, expression form and therefore very stiff. With the advancement of urbanization, the development of metropolis circle gradually spread to the surrounding city building outside the building skin due to huge size show a wonderful opportunity to perform. As early as more than a decade ago, 3D construction projection rudiment, Lyon, France light section of the old town of ancient buildings and 3D projection creatively together, a sensational [7]. However, if the construction epidermis only understand become a simple projection screen, it would be great difference, deviate from the original intention: a good understanding of the structure construction, combined with the architecture of turning and rolling lights to create works of art. Artist Elena said: "we never put the building facade as a cinema screen. First, we will observe the building appearance characteristics, expression form and building itself different external form is a kind of characteristic. As everybody has his own personality, the building also is such, let buildings become the thread of the novel. We are more like film directors, rather than the visual artist." 


\subsubsection{Light landscape.}

City in the night, because there is a light to give the "life" colour, lighting landscape is the main role, city lights section through the modelling design, functional design, and culture to explore, to form artificial landscape lighting art language. Osaka international light festival in 2016 - and Osaka.light feast, "royal hall of jin" is one of the core of the light festival, just as its name implies the royal hall bar lights is one of the main street in Osaka on dangle colored lights around the trees on both sides of the royal hall bar, $4 \mathrm{~km}$. In this city road, not only the original city structure is formed new lighting landscape, but also by building the keel, air suspension and other ways to form a new light landscape cluster. Lighting technology combining the plot and the plot and architectural lighting, make lighting art design works not only reflects the light of the latest technology, urban landscape and citizens and tourists to bring a new experience [8].

\subsubsection{Interactive Devices.}

The art design of the 21st century pays more attention to experience interaction and public participation. The promotion of participation induces the audience to communicate more directly with the author through the works of art. Interactive devices as urban lighting festival one of the main design, the fusion of people from engineering, information technology, lighting technology and programming technologies at a suit, is different from the traditional static art exhibits, interactive section let city lights more fun and vitality. According to statistics, $20 \%$ of Lyon, France international lighting section device is participative and interactive, to project the viewer into the performers, field to feedback interaction works to the crowd, inciting visitors involved in the interaction, this type of light creation is very interesting and USES a lot of new technology.

\section{OVERVIEW OF THE CREATIVE INDUSTRY.}

\subsection{Definition of Creative Industry.}

The concept of creative industry first appeared in 1998 in the British creative industry path to the file, the file is clear, "the so-called creative industries, is refers to those obtained from the individual creativity, skill and talent development power of enterprise, as well as those based on the development of intellectual property rights can create activities of potential wealth and employment opportunities." By definition, the creative industry refers to "an industry that derives from individual creativity, skill and talent, through the generation and use of intellectual property, and the potential to create wealth and employment opportunities". Creative industries, creative economy or translated into "creative industries", is a rapid development in the social background of global economic integration, creative industry to promote the creation of the team and individual ability and advanced technology of coordinated control of other disciplines, emphasis on artistic creation, design and promote cultural industry development in emerging industries, serve the local economic construction [9].

The creative industry relies on the knowledge of the team or individual that is engaged in creative work. Knowledge system, with the rapid development of modern society science and technology to create corresponding cultural resources and ascension, will eventually, creation of its research results into productive forces, to gain high value-added products, thus the cultural creative industry is the industry has the potential to create wealth and employment.

\subsection{Characteristics of the Creative Industry.}

\subsubsection{The Creative Industry Has Higher Knowledge.}

The products formed in the creative industry mainly focus on the cultural and creative ideas to be expressed, which is the objectification of people's wisdom and inspiration in the market competition. The development of cultural creative industries and information media, such as high-end electronic instrument technology is widely used in social development have close relations, compared to other industries with high knowledge and intelligent characteristics, such as a lot of film and television works through electronic imaging technology in recent years, computer special effects reduction technology and advanced vehicle combination.

\subsubsection{The Creative Industry Can Create High Added Value.}

Creative industries located in science and technology innovation and research and development and some related industrial chain of high-end link, in the field of cultural creativity research results are compatible with the high technological and artistic quality, the derivatives of social value is also higher than other products. In the cultural industry and related industry culture of science and technology innovation and product development and promotion process of the operation of the industry value chain, such as comprehensive impact on other industries, promote each other, economic and cultural value of a kind of high value-added industries.

\subsubsection{The Unique Integration of Creative Industries.}

Creative industry is the social after the revolution of science and technology, the reform of cultural system, such as after historical change, science, technology and market economy to the product of the rapid development of social economy and culture mutual fusion and exist a lot of discipline convergence.

According to the above characteristics of the creative industry, the creative industry is an important supporting force for the development of the cultural industry.

\section{THE RELATIONSHIP BETWEEN URBAN LIGHTING FESTIVAL AND CREATIVE INDUSTRY.}

The development of urban lighting festival benefits from the rise of digital media design, which is complementary to the creative industry. Before China's creative industry development level is not high, vitality and creativity is not strong, regional layout is unreasonable, policy system is not perfect, from the requirement of the pillar industries of national economy and a big distance. Enrich the connotation of the creative industry and urban lighting festival form, and the creative industries provide implementation platform for urban lighting festival, the harmony and unity between the two, to promote the rapid development of the creative industry in our country.

\subsection{The Connotation of The Creative Industry in Urban Lighting Festival.}

The urban lighting festival combines visual image art, advertising design, computer graphics, graphics and multimedia technology, etc. It is very forward-looking. Among the many available resources, the core technology of urban lighting festival -- new media technology, its application is the earliest and most practical, has been active in many fields. Therefore, the urban lighting festival has become the development booster of the urban creative industry, playing an important role in the development of the industry represented by urban culture and information development. In today's global economic integration, the development of industry in China has achieved unprecedented development, the manufacturing process has been walking in the ranks of the world's leading, many industrial technology, the implementation of the digital product research and development in the city lights make stage has an irreplaceable role.

The urban creative industries are involved in such fields as entertainment industry, cultural industry, design and publishing industry, and artistic creation. The development of its form is gradually mature and perfect, but we can't stop ourselves and find new forms of creative industry to create new value points for national production. In recent years, there have been more and more domestic cities to realize the value of the urban lighting festival, the key technology in the future will be the interaction between a man and a computer, intelligent digital production, virtual design and manufacturing, digital "operation", will be the main characteristic of the mode of production, the modern manufacturing is to informatization.

\subsection{The Urban Lighting Festival Promotes the Development of Creative Industries.}

The urban lighting festival to design the content into practice stage provided by the creative industry is inseparable from the city, it is through this platform can will make a full display technology forward-looking and sociality. From the perspective of industrial demand, there is a strong demand for information design in various fields of science and technology and industry. Information exchange and interaction class products has gradually entered People's Daily life, how to build new, from the perspective of information media communication concise and beautiful new environment, has become a high-tech human nature and the key of life.

Some major cities in China by using the rich cultural resources to get rid of high energy consumption, high investment, low energy consumption, low investment, high output model of development, vigorously develop high and new technology industry and cultural industries to become a hot spot, to combine the development of city of creative industries is not only related to the development of urban economy, the adjustment of industrial 
structure, and also related to the integration of local rich and unique culture resources, organic combination of superior resources and visual communication art the coordinated development, to form a resultant force to promote the development of cultural industry. City lights in the process of integration of resources, will be scattered field of creative industries for Mosaic, originally planned and targeted to compose, integration development, strengthen the consciousness of industry and strive to finally can meet the social formation of creative industries.

Social and economic development is the foundation of art design of prosperity, government, enterprises and institutions and small and medium-sized industry in the tide of market economy development core competition has already begun to transform cultural connotation of the competition, the most intuitive reflect this shift is art design application as the mainstay of the creative cultural industry shows vitality in the development of the society, through the analysis we know that after the resource integration of urban lighting festival to promote the development of cultural industry play an immeasurable.

\section{APPLICATION VALUE OF URBAN LIGHTING FESTIVAL IN CREATIVE INDUSTRY.}

In recent years, as people to the attention of the creative industry, city lights is blossoming, it can effectively make the cultural value, economic value and innovation of the creative industries value fully display. Therefore, our country city should be based on the characteristics of their city, looking for suitable for the urban development of creative industry development goals, to rational thinking of some cultural creative industry projects, leading the development of creative industry.
4.1 The Urban Lighting Festival Shows the Cultural Value of The Creative Industry

Digital media art design is the art design and machining process, it is a process of creating beauty, city lights section on the development of digital media art, the core value of the creative industry of city culture and art of infection. In many cities, therefore, the development of creative industries, the section by the host city for the light, can be in the creative industries of diverse and interesting visual effect for rendering, full display of the creative industry of city culture. Through dynamic images, multimedia technology and information technology to the city's culture fully tapped and promote public attention can be always fit on the cultural value, which can be of the creative industry of city culture to fully display.

In Yunnan Kunming city lighting festival, its landmark in place of "grand view pavilion park" as the main place, "night observatory" lighting festival (e.g., Figure 1). its landmark in place of "grand view pavilion park" as the main place, "night observatory" lighting festival, which are held in the lighting section three weapon using laser, drencher, sound combined with the original building, grand view pavilion culture as the main elements, on the surface of the lake in a small manufacturing water curtain light show, makes the outdoor environment the naked eye can see the $3 \mathrm{~d}$ performance. In addition, the light show will also be combined with the stage scene performance, let the actors combined with light and shadow, let the audience experience different feeling, from another Angle to enjoy bright and grand view pavilion of Yunnan culture cultural charm. And lotus on the lake landscape, using lamp tape and linked calling device, implement the lotus lamp belt with the soundtrack voices of different sizes and elegant aesthetic effects, visitors can people involved in the lotus landscape transformation interaction at the same time, the adding fun watching lanterns.

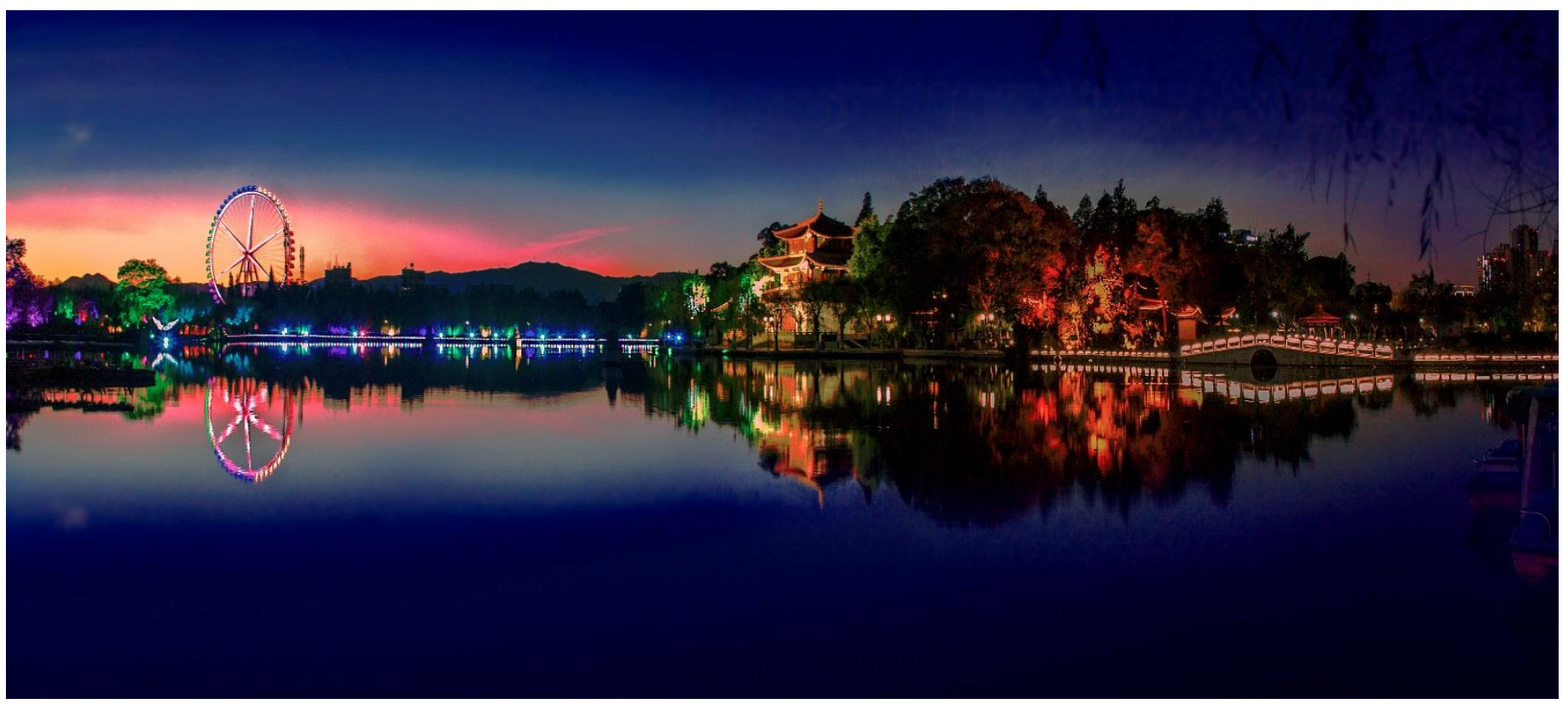

Figure 1: The view of Yunnan Kunming urban lighting festival

In the eyes of the people in Yunnan, a symbol of the grand view building exists. It combines nature and humanity, and has been the epitome of the natural environment and historical culture of Yunnan and Kunming for centuries. With the change of the city, the grand view building has become an important landscape in the modern city from the seclusion of the countryside, and the "night view" is the new blooming of the 300-plus grand view building. "night observatory, according to the grand view pavilion" historical and cultural traditions custom 23 and interactive projects, use of light and shadow art recreates the "emerald green feathers Danxia "three spring willows" "round scented rice" "nine summer hibiscus" "fine, white sand," "Tang Biao iron column" long "song with jade axe to grand view pavilion" united as the theme and artistic conception manufacturing water curtain light show on the surface of the lake, makes the outdoor environment the naked eye can see the $3 \mathrm{D}$ performance. The whole show has invested a lot of technology, capital, creativity and manpower. It has invested more than 15 million yuan and introduced dozens of high-tech means, both in front and back end technologies. In the past, grand view park was beautiful during the day, but at night it was silent and silent. "Night observatory" aroused her, let her lively, let visitors the chance to come to her, feel her fashion beautiful side, also let local and foreign tourists, have feelings of Kunming cultural new place at night. Nowadays, from the central to the local, we attach great importance to the development of tourism, and we have adopted a series of policy measures to support the development of tourism. In Yunnan province's tourism culture industry development plan (2016-2020), Yunnan province proposed to transform the development mode and promote the industrial integration and development. We should strengthen innovation drive and enhance the vitality of industrial development. Excavate new cultural value, let cultural value create brand-new city culture fashion mark.

\subsection{The Economic Value of The Creative Industry Created by The Urban Lighting Festival.}

The urban lighting festival is the most cutting-edge technology application of social development. It is a combination of the popular digital media industry, industrial design, interactive design and other industries. Therefore, as the economic core of the creative industry of city and industry core, only give full play to the city lights of economic value, to promote industrial structure adjustment of urban cultural creative industry, economic transformation and cultural creative industry development direction of revenue growth. First-tier cities and coastal developed areas in our country have come to realize that city lights brought about by the economic value, the reasonable layout of lighting design and lighting, not only the foil on the city's performance with their 
actual restore mode; At the same time, the visual communication of comfortable and creative lighting will attract a large number of people, which will stimulate and stimulate the further development of the tertiary industry (service industry) in the surrounding area.

As an important part of urban function time division, urban night time has become more and more important. The cities are mainly productive activities, and the nighttime cities are mainly consumer activities. Lighting up the city and extending the city's economic activity to the night is a huge opportunity to promote the city's economic prosperity. In the writings of "Urban Playscape of City Nightlife": "Night-time economy - - "Central to this new image has been an emphasis on the potential employment and income effects of developing a strong urban cultural economy and cultural production systems."
Guangdong province Guzhen urban international lighting festival (e.g., Figure 2), based on the ancient town of powerful lamp is acted the role of market resources, around town new town of professional development planning, as a platform with lamplight culture festival activities, so as to promote industrial upgrading and promotion for the purpose, combined with market demand, to hold the light festival in town for three consecutive years. Through rich and colorful, colorful cultural activities, the theme of the media with lamplight, lamp act the role ofing culture as the soul, the organic combination of "light culture festival" with lighting fair, promote Guzhen lighting industry transformation and upgrading, efforts to achieve "the lighting capital of China" to "the lighting capital of the world".

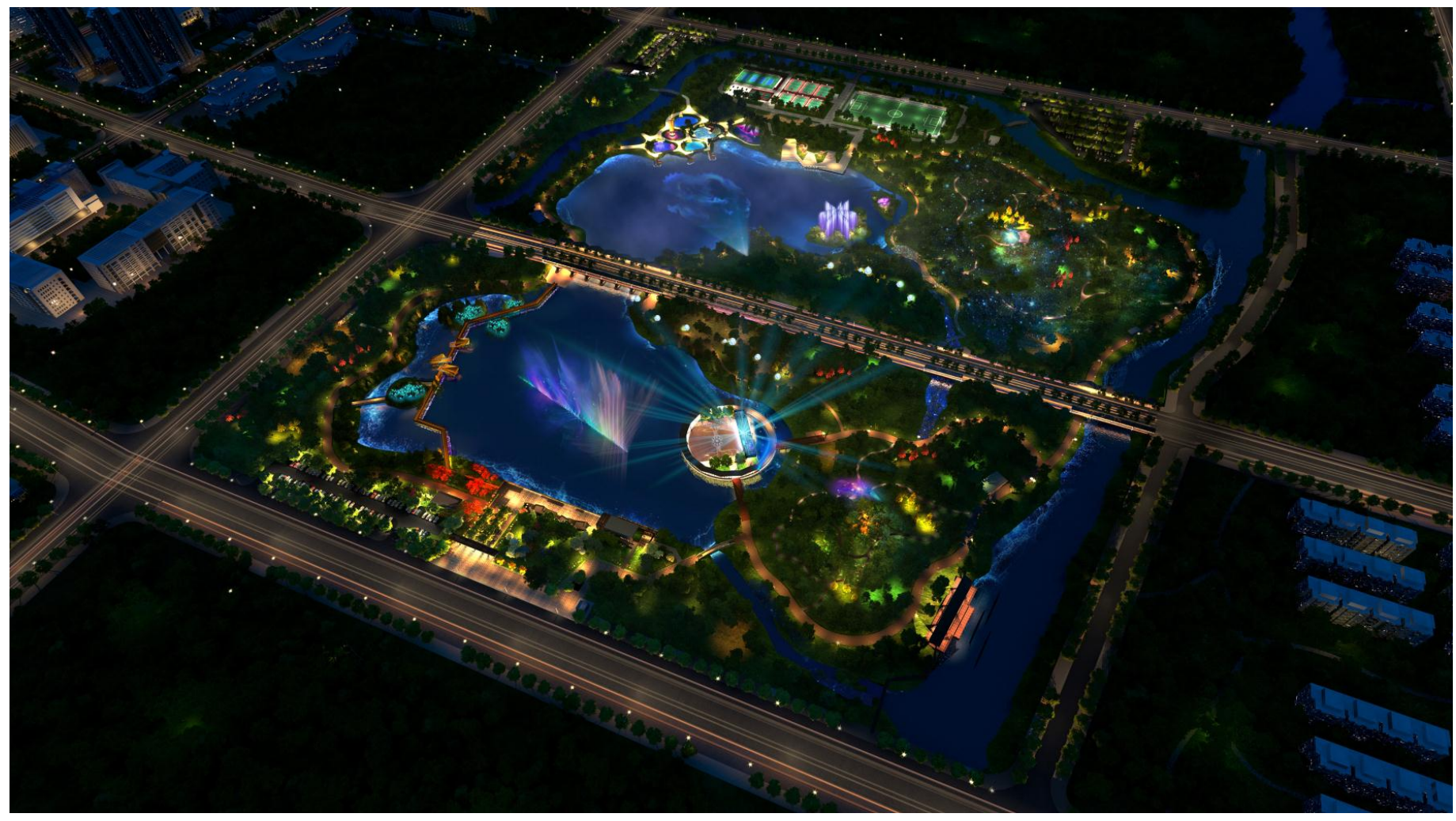

Figure 2: The view of Guzhen urban international lighting festival

The urban lighting festival in Guzhen has produced a total of us $\$ 500$ million worth of exports to more than 130 countries and regions, including Hong Kong, Macao, Taiwan, southeast Asia, Japan, the United States and Europe. The industry is spread all over the world, the radiation level is wide, the industrial chain is stable. We will promote the transformation of the urban economy from an agricultural and industrial economy to a knowledge-based economy based on innovation-driven growth.

Urban night economy cannot be separated from urban lighting construction, and urban lighting construction is divided into two categories: functional lighting and landscape lighting. Urban functional lighting construction has become an indispensable part of urban development, and urban landscape according to construction is obviously in recent years more and more attention by people and city managers. Economic effect of city functional lighting, no doubt, because it extends the time of urban economic activity, but the urban landscape lighting of the construction of the economic effect, it not only reshape the coupling space of the people, to create the new consumption reason and opportunities, city lights section is proof of that.

\subsection{To Realize the Innovation Value of Creative Industry in Urban} Lighting Festival.

The creative industry can attract wide attention and spread among urban people, because it is very creative and artistic, and has very strong appeal. Light festival is held in the urban public space of the large-scale public art activities, mainly through fusion of art and technology lighting device to show the distinctive glamour of night city, improve the brand effect of the city and making innovation value.

In the middle, the urban lighting festival in Lyon, France is recognized as the world's largest, the longest and largest lighting festival (e.g., Figure 3).
Its significance is not only a celebration activities or visual feast, it makes the industrial city of Lyon, from the original ordinary city, now outside Paris a second chamber for known French cities.

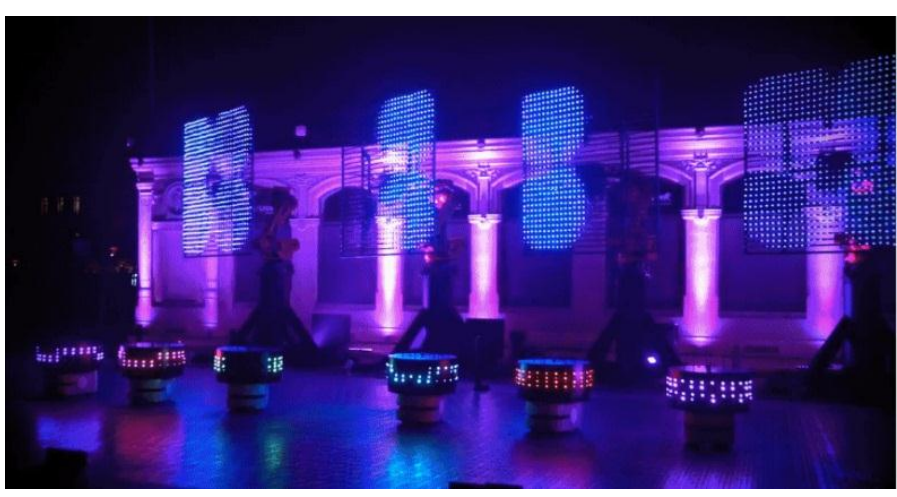

Figure 3: The view of Lyon urban lighting festival

Lyon, France urban lighting festival originated from the traditional festival celebration, festival, Lyon homes residents will burn some candles, put in the home window or on the streets, in the winter approaching, adds a trace of warmth. It is generally believed that the festival comes from the black plague epidemic period, when people think Mary will protect them from the plague, and lit the candle to pray, now Lyon urban lighting festival is derived from the ancient tradition.

Different from long-term fixed art exhibition and general lighting city sculpture, Lyon urban lighting festival every year, the theme and artistic 
effect, mostly in dynamic work is given priority to, covers the light sculpture, the building lighting, interactive device, mobile device, projection, such as performance, real light show with differentiation, diversified visual effect. At the same time, the application of the latest technology to make "light" is more attractive and sexual topics, although the whole activity last 4 days, but every year there are millions of people and tourists to feel the charm of light section.

Internationalization of professional planning and design team is the main features of Lyon urban lighting festival, every year the organizing committee of the project contract awarding ways to its global solutions, attracting large number of domestic and foreign artists and designers involved. Light during the day in 2017, Lyon, ushered in the 60's official representatives of art troupe, 32 outside of France, a total of 41 lighting art works around the city of Lyon, the internationalization of its design and production team. A large number of artists, designers, architects, sculptors, engineers work together and support each other, thus ensuring high artistic standards and influence. Through good operation mechanism, the lighting festival has become a testing ground for artists and designers, producing a large number of quality and innovative lighting works every year. A traditional festival has found a new life, a feast of high technology and art.

\section{CONCLUSION}

Creativity is a driving force for the development of the country, industry is the source of a nation's progress and development, the new exploration of the creative industries, in the contemporary art and design in the cultural background, the cultural creative industry development is very important, should with a new perspective to understand, analyze, understand the present situation of the contemporary art and design, and the possibility of future development. The multi-cultural intervention in the background of creative industry will definitely influence the diversity of contemporary art and design and the diversified pattern of richness.

In urban lighting festival, its comprehensive technical prospective and society plays an important role, and the city creative industry can achieve creative also cannot leave the culture, economy and art design support. Under the trend of social development, our city creative industry and city lighting festival will work together to build a new ecology.

\section{ABOUT THE AUTHORS}

Yue Wang, a postgraduate student at Huazhong University of science and technology, the major is new media art design.

\section{REFERENCES}

[1] Barry, J. 2007. Environment and social theory. Routledge.

[2] Landry, C., Bianchini, F. 1995. The creative city (12). Demos.

[3] Landry, C. 2012. The art of city making. Routledge.

[4] Mirri, S., Prandi, C., Roccetti, M., Salomoni, P. 2017. Walking under a Different Sky: Urban Colored Routes for Creative Engagement and Pleasure. International Journal of Human-Computer Interaction, 33 (12), 1010-1021.

[5] Chatterton, P., Hollands, R. 2002. Theorizing urban playscapes: producing, regulating and consuming youthful nightlife city spaces. Urban studies, 39 (1), 95-116.

[6] Rapoport, A. 2016. Human aspects of urban form: towards a manenvironment approach to urban form and design. Elsevier.

[7] Romice, O., Thwaites, K., Porta, S., Greaves, M., Barbour, G., Pasino, P. 2017. Urban design and quality of life. In Handbook of environmental psychology and quality of life research, Springer, Cham. 241-273

[8] Salesses, P., Schechtner, K., Hidalgo, C.A. 2013. The collaborative image of the city: mapping the inequality of urban perception. PloS one, 8 (7), e68400.

[9] Van Santen, C. 2006. Light zone city: Light planning in the urban context. Walter de Gruyter.

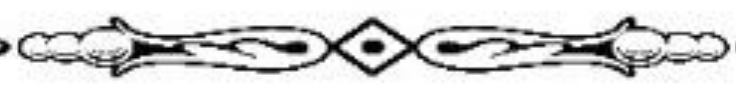

